\title{
UPAYA MENINGKATKAN PRESTASI BELAJAR SISWA DENGAN MENERAPKAN MODEL PEMBELAJARAN CLIS PADA MATA PELAJARAN IPA
}

\author{
Herta Siallagan \\ Guru SMP Negeri 1 Pangururan, Samosir \\ hertasiallagan@yahoo.com
}

\begin{abstract}
Abstrak: Tujuan penelitian tindakan kelas ini adalah Untuk mengetahui prestasi belajar siswa pada mata pelajaran IPA dengan menggunakan model pembelajaran Children Learning In Science (CLIS). Penelitian ini dilakukan di kelas VIII B Semester II Tahun Pelajaran 2014/2015. subyek penelitian adalah siswa-siswi yang memiliki tingkat inteligensi rata-rata sedang dengan jumlah siswa sebanyak 36 orang yang terdiri dari 14 laki-laki dan 22 perempuan. Data yang diperoleh dalam penelitian ini adalah bersumber dari hasil nilai pre test - post test 1, pre test - post test 2 , pre test - post test 3 dan angket minat belajar siswa, dan lembar pengamatan saat PBM terhadap pembelajaran siswa pada mata pelajaran IPA. Hasil PTK ini menunjukkan bahwa: (1) Model pembelajaran CLIS dapat meningkatkan prestasi belajar siswa khususnya pada mata pelajaran IPA, dibuktikan dengan peningkatan hasil penelitian dari Rata-rata nilai ulangan pre test I, II, III = 57,4I sedangkan Rata-rata nilai ulangan post test I, II, III = 95,74 dan semua siswa setelah dibelajarkan dengan model CLIS tidak ada yang dibawah KKM (70); dan (2) dengan meningkatnya hasil belajar dan minat belajar siswa maka prestasi belajar siswa ikut meningkat, dengan demikian guru sebagai pendidik ikut membumi landaskan Revolusi Mental bagi peserta didik dalam Menyiapkan Generasi Emas 2045.
\end{abstract}

Kata Kunci: model pembelajaran Children Learning In Science, pelajaran IPA

\begin{abstract}
The aim of this action research was to determine student achievement in science subjects using learning models Children Learning In Science (CLIS). The research was done in class VIII B Semester II 2014/2015 academic year, the study subjects were students who has the intelligence level average being the number of students as many as 36 people consisting of 14 men and 22 women. The data obtained in this study were derived from the results of the pre test - post test 1, pre test-post test 2, pre test - post test 3 and questionnaires interest in student learning, and sheets of observations when PBM to student learning in science subjects. The results of PTK showed that: (1) learning model CLIS can improve student achievement, especially in science subjects, evidenced by the increase the results of the average value of restating pre test I, II, III $=57.41$ while the average posttest replay value I, II, III = 95.74 and all the students after dibelajarkan CLIS model with nothing under the KKM ( 70); and (2) with increased learning outcomes and student interest in learning the student achievement also increased, thus teachers as educators participated grounded grounded Mental Revolution for learners in Setting up the 2045 Golden Generation.
\end{abstract}

Keywords: Children learning model Learning In Science, a science lesson

\section{PENDAHULUAN}

Di Sekolah Menengah Pertama (SMP) ada 4 mata pelajaran yang di UN kan, yang salah satunya adalah mata pelajaran IPA. Mata Pelajara IPA termasuk mata pelajaran yang sulit bagi secara umum siswa, sehingga hasil belajar IPA banyak yang rendah. Salah satu tujuan pembelajaran IPA di SMP yaitu agar siswa menguasai berbagai konsep dan prinsip IPA untuk mengembangkan pengetahuan, keterampilan, dan sikap percaya diri sehingga dapat diterapkan dalam kehidupan sehari-hari dan sebagai bekal untuk melanjutkan pendidikan pada jenjang yang lebih tinggi. Pembelajaran IPA di SMP juga dimaksudkan untuk membentuk sikap yang positif, yaitu merasa tertarik untuk mempelajarinya, sehingga dapat menerapkannya dalam teknologi (Subratha, 2007: 135-136). Namun, jika penguasaan konsep-konsep dan prinsip-prinsip IPA sangat rendah disertai dengan sikap negatif terhadap pelajaran IPA, sulit diharapkan siswa akan berhasil dengan baik dalam pembelajaran di kelas. 
Berdasarkan observasi awal pada bulan Februari 2015 dengan mengamati kegiatan pembelajaran oleh guru mata pelajaran di kelas VIII B diperoleh data sebagai berikut: (1) dari nilai Ulangan Harian BAB.I dan BAB.II bahwa hasil belajar peserta didik mata pelajaran IPA sangat rendah karena lebih dari 10 orang nilainya dibawah KKM (70). (2) peserta didik terlihat diam dan pasif jika ada materi yang belum dipahami. (3) peserta didik kurang percaya diri untuk mengemukakan pendapat dan memberikan pertanyaan kepada guru maupun teman. (4) selama pelajaran berlangsung peserta didik kurang berdiskusi antar teman sebangku maupun teman sekelas, karena hanya menyelesaikan tugas masing-masing. Beberapa faktor yang dipandang sebagai penyebab masalah tersebut sebagai berikut: (1) metode pembelajaran yang digunakan oleh guru monoton dan kurang memancing kreatifitas siswa. (2) jika terdapat kesalahan jawaban atau siswa tidak mengerti, guru langsung menjelaskan materi tersebut tanpa memberikan kesempata pada peserta didik lain untuk menjawabnya; dan (3) guru lebih tertarik pada jawaban peserta didik yang benar tanpa menganalisis kesalahan-kesalahan yang dilakukan siswa dan prosedur penyelesaiannya.

Untuk mengatasi masalah tersebut, maka penulis perlu menggunakan model pembelajaran yang tepat sasaran. Oleh karena itu guru harus mampu membenahi dirinya dengan cara menyesuaikan diri dengan cepat dan tepat, mengembangkan sistem pendidikan dengan inovasi kreatif dan bersahabat dengan kebutuhan peserta didik, sehingga putra-putri yang dihasilkan oleh pendidikan Indonesia dapat bersaing dan tetap survive ditengah kemajuan pendidikan negara-negara lain secara global. Dari penjelasan di atas, perlu adanya metode/model pembelajaran yang dapat meningkatkan hasil belajar pada ranah kognitif yang lebih tinggi dan interaksi siswa. Karakteristik pelajaran IPA terdiri dari banyak konsep dan prinsip penting, sehingga untuk proses belajar IPA diperlukan model pembelajaran yang tepat agar siswa lebih aktif belajar dan diharapkan hasil belajar siswa lebih baik dan nantinya prestasi belajar siswa akan semakin meningkat. Penulis memikirkan model pembelajaran apa lagi yang harus penulis buat untuk meningkatkan keaktifan siswa dalam belajar sehingga prestasi belajarnya dapat meningkat? Lalu penulis punya ide yaitu dengan menerapkan model CLIS mungkin dapat lebih meningkatkan prestasi siswa. Diharapkan model pembelajaran CLIS ini dapat meningkatkan hasil belajar siswa sehingga prestasi siswa juga dikatakan semakin meningkat. Dengan demikian pendidikan di Indonesia dapat menjadi pemain dan pemenang dalam persaingan dunia yang semakin ketat dan bukan sebagai penonton. Karena jaminan kelangsungan hidup bangsa Indonesia di masa mendatang ditentukan oleh prestasi siswa Indonesia di masa sekarang.

Prestasi belajar diartikan sebagai tingkat keterkaitan siswa dalam proses belajar mengajar sebagai hasil evaluasi yang dilakukan guru. Djamarah menyatakan bahwa: "Prestasi belajar adalah hasil yang diperoleh berupa kesan-kesan yang mengakibatkan perubahan dalam diri individu sebagai hasil dari aktivitas dalam belajar". Prestasi belajar inilah yang disebut tingkat penguasaan yang dicapai dan diperoleh siswa setelah mengikuti program belajar-mengajar sesuai tujuan yang ditetapkan.

Menurut Tirtonegoro (1984: 4), mengemukakan bahwa : Prestasi belajar adalah penilaian hasil usaha kegiatan belajar yang dinyatakan dalam bentuk symbol angka, huruf maupun kalimat yang dapat mencerminkan hasil yang sudah dicapai oleh setiap anak didik dalam periode tertentu. Menurut Partini (1980: 49), "Prestasi belajar adalah hasil yang dicapai oleh seseorang dalam kegiatan belajar". Sejalan dengan pendapat itu Sunarya (1983: 4) menyatakan "Prestasi belajar merupakan perubahan tingkah laku yang meliputi ranah kognitif, afektif, dan psikomotorik yang merupakan ukuran keberhasilan siswa". Ketut (1983: 51), menyatakan "Untuk mengukur prestasi belajar menggunakan tes prestasi yang dimaksud sebagai alat untuk mengungkap kemampuan aktual sebagai hasil belajar atau learning".

Belajar senantiasa diikuti oleh perubahan tingkah laku atau penampilan. Perubahan yang dimaksud adalah perubahan tingkah laku yang positif sebagai tujuan yang hendak dicapai dari aktivitas belajar tersebut. Aktivitas belajar menjadi bermakna bila guru mampu memusatkan segala kemampuan mental siswa dalam program kegiatan tertentu. Oleh karena itu guru sebaiknya membuat pembelajaran dalam pengajaran yang menyebabkan siswa aktif, kreatif, efektif dan menyenangkan. Aktivitas belajar yang optimal tersebut akan menghasilkan prestasi belajar yang optimal pula yang dapat dijadikan sebagai indikator untuk mengetahui kemajuan individu para siswa dalam memperoleh pembelajaran disekolah. 
Prestasi belajar merupakan ukuran keberhasilan yang diperoleh siswa selama proses belajarnya. Keberhasilan itu ditentukan oleh berbagai faktor yang saling berkaitan. Menurut Mahmud (1989: 84-87), mengatakan bahwa Faktor-faktor yang mempengaruhi prestasi belajar siswa mencakup : "faktor internal dan faktor eksternal". sebagai berikut: (1) faktor internal adalah faktor yang berasal dari dalam diri siswa itu sendiri, yang terdiri dari N. Ach (Need For Achievement) yaitu kebutuhan atau dorongan atau motif untuk berprestasi; (2) faktor eksternal adalah faktor yang berasal dari luar si pelajar. Hal ini dapat berupa sarana prasarana, situasi lingkungan baik itu lingkungan keluarga, sekolah maupun lingkungan masyarakat. Menurut pendapat Rooijakkers yang diterjemahkan oleh Soenoro (1982: 30), mengatakan bahwa "Faktor yang mempengaruhi prestasi belajar adalah faktor yang berasal dari si pelajar, faktor yang berasal dari si pengajar". Kedua faktor tersebut dapat dijelaskan sebagai berikut : (a) faktor yang berasal dari si pelajar (siswa). Faktor ini meliputi motivasi, perhatian pada mata pelajaran yang berlangsung, tingkat peneirmaan dan pengingatan bahan, kemampuan menerapkan apa yang dipelajari, kemampuan mereproduksi dan kemampuan menggeneralisasi; (b) faktor yang berasal dari si pengajar (Guru). Faktor ini meliputi kemampuan membangun hubungan dengan si pelajar, kemampuan menggerakkan minat pelajaran, kemampuan memberikan penjelasan, kemampuan menyebutkan pokok-pokok masalah yang diajarkan, kemampuan mengarahkan perhatian pada pelajaran yang sedang berlangsung, kemampuan memberikan tanggapan terhadap reaksi.

Menurut Syah (2006: 144) bahwa prestasi belajar siswa dipengaruhi oleh setidaknya tiga faktor yakni: (a) faktor internal, yaitu faktor yang ada dalam diri individu yang sedang belajar, faktor intern terdiri dari: (1) faktor jasmaniah yang meliputi kesehatan dan cacat tubuh.,(2) faktor psikologis yang meliputi tingkat inteligensi, perhatian, minat, bakat, motif, kematangan dan kesiapan. (3) faktor kelelahan. (b) faktor eksternal, yaitu faktor dari luar individu. Faktor ekstern terdiri dari: (1) faktor keluarga yaitu cara orang tua mendidik, relasi antara anggota keluarga, suasana rumah, keadaan ekonomi keluarga, pengertian orang tua, dan latar belakang kebudayaan. (2) faktor dari lingkungan sekolah yaitu metode mengajar guru, kurikulum, relasi guru dengan siswa, relasi siswa dengan siswa, disiplin sekolah, alat pelajaran, waktu sekolah, standar belajar diatas ukuran, keadaan gedung, metode belajar dan tugas rumah. (3) faktor masyarakat yaitu kegiatan siswa dalam masyarakat, mass media, teman bergaul, dan bentuk kehidupan masyarakat. (c) faktor pendekatan belajar (approach to learning), yakni jenis upaya belajar siswa yang meliputi strategi dan metode yang digunakan siswa untuk melakukan kegiatan pembelajaran materi-materi pelajaran.

Dari penjelasan diatas dapat disimpulkan bahwa faktor yang mempengaruhi prestasi belajar siswa ada dari dalam diri siswa dan ada dari luar diri siswa termasuk faktor pendekatan belajar (approach to learning). Penulis menyatakan bahwa prestasi belajar siswa dipengaruhi oleh dua faktor yaitu faktor yang berasal dari diri pelajar (siswa) dan faktor yang berasal dari si pengajar (guru). Faktor ini meliputi kemampuan membangun hubungan dengan si pelajar, kemampuan menggerakkan minat pelajaran, kemampuan memberikan penjelasan, kemampuan menyebutkan pokokpokok masalah yang diajarkan, kemampuan mengarahkan perhatian pada pelajaran yang sedang berlangsung, kemampuan memberikan tanggapan terhadap reaksi.

Pada penelitian ini, Penulis khusus membahas faktor dari luar diri siswa yaitu guru atau pengajar. Dengan berbagai metode atau model pembelajaran dan pendekatan atau strategi pembelajaran yang tepat dilakukan oleh guru, akan meningkatkan prestasi belajar siswa. Seperti penggunaan model pembelajaran CLIS sangat cocok dengan mata pelajaran IPA, karena materinya secara umum dapat di lihat, diamati oleh siswa sehingga memungkinkan para siswa semakin semangat mengikuti PBM. Disamping guru menggunakan model pembelajaran CLIS, guru juga harus terampil dan mau malakukan pembelajaran dengan menggunakan alat pelajaran (alat-alat laboratorium, alat/ benda dan bahan yang nyata) atau media pembelajaran (animasi pembelajaran, video pembelajaran, CD iteraktif, gambar-gambar menarik, makro flas yang berhubungan dengan materi pelajaran . Melalui PBM yang menarik seperti itulah para siswa mampu memberikan gagasan-gagasannya secara berulang-ulang sampai siswa paham betul materi pelajaran yang mereka pelajari.

IPA berasal dari kata sains yang berarti alam. Sains menurut Suyoso (1998:23) merupakan "pengetahuan hasil kegiatan manusia yang bersifat aktif dan dinamis tiada hentihentinya serta diperoleh melalui metode tertentu yaitu teratur, sistematis, berobjek, bermetode 
dan berlaku secara universal ". Menurut Abdullah (1998:18), IPA merupakan pengetahuan teoritis yang diperoleh atau disusun dengan cara eksperimentasi, observasi dan demikian seterusnya kait mengkait antara cara yang satu dengan cara yang lain. Pendidikan IPA menurut Tohari (1978:3) merupakan "usaha untuk menggunakan tingkah laku siswa hingga siswa memahami proses-proses IPA, memiliki nilai-nilai dan sikap yang baik terhadap IPA serta menguasai materi IPA berupa fakta, konsep, prinsip, hukum dan teori IPA". Pendidikan IPA menurut Sumaji (1998: 46) merupakan "suatu ilmu pengetahuan Alam yang merupakan disiplin ilmu bukan bersifat teoritis saja melainkan gabungan (kombinasi) antara disiplin ilmu yang bersifat produktif ". Dari pendapat tersebut penulis menyimpulkan bahwa pendidikan IPA merupakan suatu usaha yang dilakukan secara sadar untuk mengungkap gejala-gejala alam dengan menerapkan langkahlangkah ilmiah serta untuk membentuk kepribadian atau tingkah laku siswa sehingga siswa dapat memahami proses IPA dan dapat dikembangkan di masyarakat. Dalam menyelenggarakan pembelajaran dengan aktivitas belajar efektif yang mengarah kepada pencapaian prestasi belajar yang optimal tersebut, dunia pendidikan mata pelajaran IPA dibelajarkan dengan model Pembelajara Children Learning In Science (CLIS).

Model pembelajaran adalah kerangka konseptual yang melukiskan prosedur yang sistematis dalam mengorganisasikan pengalaman belajar untuk mencapai tujuan tertentu dan berfungsi sebagai pedoman bagi perancang pengajaran, seperti dikemukakan oleh Rohimah (2002;9). Dahlan dalam Nurlela (2001:1) mengatakan bahwa suatu model mengajar dapat diartikan sebagai suatu rencana atau pola yang digunakan dalam penyusunan kurikulum, mengatur materi pelajaran dan memberi petunjuk kepada pengajar dikelas. Model pembelajaran merupakan rencana dalam mengajar yang direkayasa sedemikian rupa untuk mencapai tujuan tertentu dalam pembelajaran. Rencana pembelajaran ini meliputi perencanaan, pelaksanaan dan evaluasi pembelajaran.

Model pembelajaran CLIS merupakan model pembelajaran yang berusaha mengembangkan ide atau gagasan siswa tentang suatu masalah tertentu dalam pembelajaran serta merekonstruksi ide atau gagasan berdasarkan hasil pengamatan, obsevasi atau mencermati buku teks. Dimana dalam pembelajaran ini siswa diberi kesempatan untuk mengungkapkan berbagai gagasan tentang topik yang dibahas dalam pembelajaran, mengungkapkan gagasan serta membandingkan gagasan dengan gagasan siswa lainnya dan mendiskusikannya untuk menyamakan persepsi. Selanjutnya siswa diberi kesempatan merekontruksi gagasan setelah membandingkan gagasan tersebut dengan hasil percobaan, observasi atau hasil mencermati buku teks. Di samping itu, siswa juga mengaplikasikan hasil rekontruksi gagasan dalam situasi baru (Tina, 2009: 5).

Suyatna (2007: 40-42) menyatakan bahwa model pembelajaran CLIS dikembangkan oleh kelompok Children's Learning in Science di Inggris yang dipimpin oleh Driver (1988) dan Tytler (1996). Rangkaian fase pembelajaran pada model CLIS oleh Driver (1988) diberi nama general strukture of a construkctivist theaching sequence, sedangkan Tytler (1996) menyebutnya constructivisme and conceptual change views of learning in science.

Model pembelajaran CLIS terdiri atas sederetan Langkah-langkah kegiatan yang dilakukan siswa dalam mempelajari konsepkonsep IPA yang meliputi 5 (lima) Fase, yaitu : (1) Orientasi (Orientation); (2) pemunculan gagasan (elicitation of ideas); (3) penyusunan ulang gagasan (restructuring of ideas) dengan tiga langkah antara lain (a) pengungkapan dan pertukaran gagasan (clarification and exchange); (b) pembukaan situasi konflik (exposure to conflict situation); (c) konstruksi gagasan baru dan evaluasi (construction of new ideas and evaluation); (4) penerapan gagasan (application of ideas); dan (5) mengkaji ulang gagasan dan perubahan gagasan (review change in ideas). (Marselina, 2008)

Faktor terpenting dalam pelaksanaan model pembelajaran CLIS antara lain: (1) menciptakan situasi belajar terbuka dan memberikan kebebasan pada siswa dalam mengemukakan ide atau gagasannya; (2) memberikan kesempatan pada setiap siswa untuk bertanya secara bebas dengan teman atau gurunya. Kemudian pada akhir kegiatan guru menjelaskan konsep-konsep ilmiah untuk menghindari miskonsepsi pada siswa; (3) memberikan tugas perorangan yang dikerjakan siswa di rumah berupa pekerjaan rumah sebagai penerapan konsep kemudian hasilnya didiskusikan kembali oleh siswa dikelas. (Adey, 1989 dalam Handayani, 2002:22)

$$
\text { Urutan pembelajaran model }
$$

pembelajaran CLIS: 
a. Orientasi. Orientasi merupakan upaya guru untuk memusatkan perhatian siswa, misalnya dengan menyebutkan atau mempertontonkan suatu fenomena yang sering terjadi dalam kehidupan sehari-hari, yang berkaitan dengan topik yang dipelajarai. Upaya mengaitkan topik yang akan dipelajari dengan fenomena lingkungan (misalnya berbagai macam makanan dalam kehidupan sehari-hari) juga merupakan salah satu kegiatan dalam penggunaan pendekatan CTL.

b. Pemunculan gagasan. Pemunculan gagasan merupakan upaya untuk memunculkan konsepsi awal siswa. Misalnya dengan cara meminta siswa menuliskan apa saja yang telah diketahui tentang topik pembicaraan, atau dengan menjawab beberapa pertayaan uraian terbuka. Bagi guru tahapan ini merupakan upaya eksplorasi pengetahuan awal siswa. Oleh karena itu tahapan ini dapat juga dilakukan melalui wawancara informal.

c. Penyusunan ulang gagasan. Pengunkapan dan pertukaran gagasan mendahului pembukaan kesituasi konflik. Tahap ini merupakan upaya untuk memperjelas atau mengungkapkan gagasan awal siswa tentang suatu topik secara umum, misalnya dengan cara mendiskusikan jawaban siswa pada langkah kedua dalam kelompok kecil, kemudian salah satu anggota kelompok melaporkan hasil diskusi tersebut kepada seluruh kelas. Guru tidak membenarkan atau menyalahkan. Pada tahap pembukaan kesituasi konflik siswa diberi kesempatan untuk mencari pengertian ilmiah yang sedang dipelajari di dalam buku teks. Selanjutnya siswa mencari beberapa perbedaan antara konsepsi awal mereka dengan konsep ilmiah yang ada dalam buku teks atau hasil pengamatan terhadap kegiatan yang dilakukan. Tahap konstruksi gagasan baru dan evaluasi dilakukan untuk mencocokkan gagasan yang sesuai dengan fenomena yang dipelajari guna mengkonstruksi gagasan baru. Siswa diberi kesempatan untuk melakukan percobaan dan observasi, kemudian mendiskusikannya dengan kelompoknya.

d. Penerapan gagasan. Pada tahap ini siswa diminta menjawab pertanyaan yang disusun untuk menerapkan konsep ilmiah yang diterapkan konsep ilmiah yang telah dikembangkan siswa melalui percobaan atau observasi ke dalam situasi baru. Gagasan yang sudah direkonstruksi ini dalam aplikasinya dapat digunakan untuk menganalisis isu-isu dan memecahkan masalah yang ada dilingkungan, misalnya isu yang berkaitan dengan topik pernapasan adalah mewabahnya influenza, isu kanker paru-paru sebagai penyakit yang menimbulkan kematian, dan adanya orang yang meninggal karena berada di ruangan tertutup pakai genset.

e. Pemantapan gagasan. Konsepsi yang telah diperoleh siswa perlu diberi umpan balik oleh guru untuk memperkuat konsep ilmiah tersebut. Dengan demikian diharapkan siswa yang konsepsi awalnya tidak konsisten dengan konsep ilmiah dengan sadar akan mengubah konsepsi awal menjadi konsep ilmiah. Pada kesempatan ini dapat juga diberi kesempatan membandingkan konsep ilmiah yang sudah disusun dengan konsep awal pada tahap berikutnya.

Model pembelajaran CLIS memiliki kelebihan. Kelebihan-kelebihan dimaksud adalah : membiasakan siswa untuk belajar secara mandiri dalam mengatasi suatu permasalahan; (1) menciptakan kreatifitas siswa untuk belajar, sehingga terciptanya suasana kegiatan belajar mengajar yang konduksif; (2) terjalinnya kerjasama antar siswa di dalam kelompoknya pada saat melakukan kegiatan; (3) suasana belajar lebih bermakna, karena siswa menemukan sendiri hasil pengamatan dan percobaannya; (4) guru mengajar akan lebih mudah hanya mengarahkan setiap konsep yang diajarkan kearah yang lebih benar dan dapat menciptakan suasana belajar yang lebih aktif; (5) guru hanya menyiapkan berbagai masalah yang ada hubungannya dengan konsep yang akan diajarkan; (6) siswa menjawab sendiri pertanyaan yang terdapat di LKS secara mandiri maupun kelompok; dan (7) guru dapat menemukan alat-alat atau media pengajaran yang mudah didapati di dalam kehidupan sehari-hari. Adapun yang menjadi rumusan masalah dalam penelitian ini adalah: Apakah model pembelajaran Children Learning In Science (CLIS) dapat meningkatkan prestasi belajar siswa pada mata pelajaran IPA di SMP Negeri 1 Pangururan?

\section{METODE}

Penelitian ini dilakukan di kelas VIII B SMP Negeri 1 Pangururan Kabupaten Samosir pada Semester II Tahun Pelajaran 2014/2015. Subyek penelitian ini adalah siswa-siswi yang memiliki tingkat inteligensi rata-rata sedang dengan jumlah siswa sebanyak 36 orang yang terdiri dari 14 orang laki-laki dan 22 orang 
perempuan. Siswa ini adalah para siswa kelas Regular (non unggulan) yang telah memenuhi standar nilai ujian masuk yang ditetapkan pada saat penerimaan murid baru, sehingga memiliki kemampuan intelektual yang sedang.

Data yang diperoleh dalam penelitian ini adalah bersumber dari hasil nilai pre test 1 dan post test 1 , pre test 2 dan post test 2, pre test 3 dan post test 3 para siswa dalam semester genap Tahun Ajaran 2014/2015 dan angket minat belajar siswa, dan lembar pengamatan saat PBM dengan menggunakan model CLIS terhadap pembelajaran siswa pada mata pelajaran IPA.

Teknik dan alat pengumpulan data dilakukan dalam penelitian ini adalah dengan cara melakukan penilaian terhadap hasil nilai pre test - post test1, pre test - post test 2, pre test post test 3. Kemudian nilai tersebut direkapitulasi dalam bentuk tabel nilai yang disusun berdasarkan urutan abjad nama lalu diolah sesuai dengan kebutuhan penelitian. Selanjutnya kepada para siswa dibagikan angket minat belajar dengan jumlah siswa 36 orang .

Data yang diperoleh dan diolah dalam penelitian ini adalah data asli dan akurat dari keseluruhan proses mulai dari perencanaan pembelajaran, penyusunan soal, pelaksanaan pembelajaran, pelaksanaan ulangan pre tast dan post test, memberikan angket tentang tingkat kepuasan pembelajaran dengan model CLIS, hingga melakukan rekapitulasi nilai para siswa khususnya mata pelajaran IPA yang keseluruhan proses tersebut dilaksanakan dan berada dalam pengawasan penulis sendiri. Selain itu soal-soal ujian disajikan dalam sistem pilihan berganda sehingga memberikan standar penilaian akurat dan objektif, dan nilai hasil ujian direkapitulasi untuk memperoleh nilai rata-rata siswa per individu dan nilai rata-rata siswa perkelas sehingga validitas nilai yang diperoleh lebih akurat dan dijamin kebenarannya. Disamping itu untuk menunjukkan keakuratanya, penulis membuat video pembelajaran yang dapat menunjukkan semua peristiwa-peristiwa yang sesuai dengan langkah-langkah model pembelajaran CLIS.

Dalam penelitian ini, penulis mengolah data dengan mengorganisir hasil nilai pre test - post test1, pre test - post test 2 , pre test - post test 3. Kemudian terhadap hasil nilai ujian tersebut dilakukan pengolahan data untuk memperoleh nilai rata-rata pre tast, nilai rata-rata post test baik siswa per individu maupun nilai rata-rata siswa perkelas. Data yang diolah tersebut kemudian dilakukan perbandingan.
Hasil perbandingan tersebut kemudian di sinergiskan dengan hasil pemberian angket tingkat kepuasan siswa yang melakukan pembelajaran tidak menggunakan model CLIS dengan hasil pemberian angket tingkat kepuasan siswa di kelas VIIIB yang melakukan pembelajaran dengan menggunakan model CLIS .Untuk persiapannya disediakan daftar Nilai Kelas VIII B, daftar angket motivasi siswa, dan daftar penilaian kinerja guru.

\section{HASIL DAN PEMBAHASAN \\ Hasil}

Kondisi awal dalam PTK mata pelajaran IPA ini adalah bahwa para siswa yang diteliti adalah para siswa yang berada dalam tingkat pendidikan yang sedang. Para siswa ini adalah para siswa kelas Regular (non unggulan) yang telah memenuhi standar nilai ujian masuk yang ditetapkan pada saat penerimaan murid baru, sehingga memiliki kemampuan intelektual yang sedang.

Pembelajaran dilakukan oleh penulis sendiri dengan menyajikan materi mata pelajaran IPA ke tiga pokok materi yaitu sistem pernafasan pada manusia, sistem pencernaan pada manusia, dan sistem peredaran darah pada manusia. Penelitian Tindakan Kelas ini dilakukan dalam 3 siklus yaitu siklus I, siklus II dan siklus III yang melakukan pembelajaran dengan menggunakan model CLIS .

Siklus pertama dilakukan dengan cara membelajarkan para siswa dengan pemberian materi bahasan Sistem Pernapasan pada Manusia yaitu Proses Pernapasan dan Volume udara pernapasan. dibelajarkan dengan menggunakan model CLIS dengan langkahlangkah kegiatan pertama di uji dahulu pengetahuan awalnya dengan mengadakan pre test dengan waktu 5 menit, Guru menghubungkan materi yang lewat dengan materi sekarang, menghubungkan materi sekarang dengan lingkungan atau kenyataan, selanjutnya menyajikan Video menarik tentang Kapasitas Vital Paru-paru, Mengumpulkan gagasan gagasan dan pertanyaan dari siswa tentang video pembelajaran, menguji cobakan gagasan dengan melakukan praktek mengukur kavasitas vital paru-paru, menghubungkan gagasan dengan hasil praktek, kemudian guru dan siswa melakukan refleksi dan mengambil kesimpulan, selanjutnya di uji cobakan dengan menjawab post test, dengan alokasi waktu juga 5 menit, selanjutnya membahas post test dan memberikan tugas rumah. 
Siklus kedua dilakukan dengan cara membelajarkan para siswa dengan materi bahasan Sistem Pencernaan makanan pada Manusia dengan sub konsep makanan. Dibelajarkan dengan menggunakan model CLIS dengan langkah-lankah kegiatan pertama-tama di uji dahulu pengetahuan awalnya dengan mengadakan pre test dengan waktu 5 menit, selanjutnya Guru menghubungkan materi yang lewat dengan materi sekarang, menghubungkan materi sekarang dengan lingkungan atau kenyataan, menyuruh siswa untuk mengisap nasi menunjukkan pencernaan kimiawi, menyuruh siswa untuk menggiling pil tablet untuk memberikan pemahaman tentang pencernaan mekanis, lalu menunjukkan cd interaktif pencernaan mekanis dan kimiawi, menunjukkan gambar-gambar zat-zat makanan .Mengumpulkan gagasan gagasan dari siswa tentang fungsi makanan, pencernaan mekanis dan kimiawi, dan mengumpulkan gagasan dari zat-zat makanan, menguji cobakan gagasan dengan melakukan praktek menguji zat makanan, menghubungkan gagasan dengan hasil praktek, guru dan siswa melakukan refleksi dan mengambil kesimpulan, selanjutnya di uji cobakan dengan menjawab post test, dengan alokasi waktu juga 5 menit, selanjutnya membahas post test dan memberi tugas rumah.

Siklus ketiga dilakukan dengan cara membelajarkan para siswa dengan materi bahasan Sistem Peredaran darah pada Manusia dengan sub konsep darah. dibelajarkan dengan menggunakan model CLIS dengan langkahlankah kegiatan pertama-tama di uji dahulu pengetahuan awalnya dengan mengadakan pre test dengan waktu 5 menit, selanjutnya Guru menghubungkan materi yang lewat dengan materi sekarang, menghubungkan materi sekarang dengan lingkungan atau kenyataan, menyuruh siswa untuk menceritakan peristiwa yang pernah terjadi dalam hidupnya keluar darah lalu menjelaskan apa penyebab keluarnya darah tersebut, lalu menunjukkan cd interaktif/video singat tentang fungsi darah. menunjukkan gambar-gambar macam-macam darah. Mengumpulkan gagasan gagasan dari siswa tentang fungsi darah, macam-macam darah, dan mengumpulkan gagasan dari ciri-ciri (bentuk dan warna) dan fungsi masing-masing bagian darah dalam tubuh manusia, menguji cobakan gagasan dengan melakukan praktek mengamati bentuk bentuk darah menggunakan mikroskop, menghubungkan gagasan dengan hasil praktek, guru dan siswa melakukan refleksi dan mengambil kesimpulan, selanjutnya di uji cobakan dengan menjawab post test, dengan alokasi waktu juga 5 menit, selanjutnya membahas post test dan memberi tugas rumah.

Sesuai dengan karakteristik variabel yang akan diteliti, penulis mengumpulkn data dengan menggunakan :

1. Ulangan yang dilaksanakan sebelum dibelajarkan dengan model pembelajaran CLIS sebanyak 3 kali yaitu pre test 1 , pre test2, pre test 3 untuk 3 sub topik pembelajaran pada materi pembahasan IPA sebagaimana diuraikan dalam deskripsi siklus. Jumlah soal yang diujikan masingmasing sebanyak 5 soal. Ujian Pre test tersebut dilaksanakan setelah dibelajarkan dengan model pembelajaran CLIS sebanyak 3 kali yaitu post test 1 , post test 2, post test 3 untuk 3 sub topik pembelajaran pada materi pembahasan IPA sebagaimana diuraikan dalam deskripsi siklus. Jumlah soal yang diujikan masing-masing sebanyak 5 soal. Ujian post test tersebut dilaksanakan.

2. Lembar angket tentang minat siswa belajar dengan menggunakan CLIS sebanyak 36 lembar yang dibagikan kepada 36 siswa.

Teknik analisis data kinerja guru dalam menggunakan model pembelajaran CLIS dilakukan dengan menggunakan teknik analisis kualitatif, karena data yang diperoleh berbentuk kategori/kualitatif. Teknik analisis data kinerja guru pada setiap siklus dilakukan dengan cara mengisi lembar penilaian.

Sebelum melakukan Penelitian Tindakan Kelas penulis melakukan beberapa persiapan penelitian antara lain :

1. Mempersiapkan kelompok belajar yang terdiri dari 8 kelompok sebagaimana dijelaskan diatas.

2. Mempersiapkan perangkat pembelajaran yang menarik dengan menggunakan alat dan bahan yang nyata yang ada di lingkungan sekitar dan menyusunnya dengan menggunakan Lap top dan Infokus berupa penyajian gambar-gambar menarik, $\mathrm{CD}$ interaktif, video yang berhubungan dengan pelajaran dan berbagai animasi menarik yang disajikan dalam bentuk power point.

3. Mempersiapkan alat test berupa soal pilihan berganda yang dilakukan sebanyak 3 kali pre test dan 3 kali post test.

4. Mempersiapkan angket yang menanyakan minat siswa terhadap pembelajaran menggunakan CLIS kepada para siswa. 
Tabel 1. Hasil perolehan nilai ulangan sebelum menerapkan model pembelajaran CLIS di kelas VIIIB

\begin{tabular}{|c|c|c|c|c|c|}
\hline No & Nama Siswa & Pre Test 1 & Pre Test 2 & Pre test 3 & Nilai rata-rata \\
\hline 1. & AN1 & 60 & 80 & 60 & 66,67 \\
\hline 2. & AS & 60 & 60 & 60 & 60,00 \\
\hline 3. & AN2 & 60 & 60 & 60 & 60,00 \\
\hline 4. & AN3 & 40 & 80 & 80 & 66,67 \\
\hline 5. & BS & 60 & 60 & 60 & 60,00 \\
\hline 6. & $\mathrm{BN}$ & 60 & 80 & 40 & 60,00 \\
\hline 7. & BT & 60 & 60 & 40 & 53,33 \\
\hline 8. & $\mathrm{BM}$ & 60 & 80 & 0 & 46,67 \\
\hline 9. & DS & 60 & 60 & 60 & 60,00 \\
\hline 10. & DG & 60 & 80 & 0 & 46,67 \\
\hline 11. & EN & 60 & 60 & 60 & 60,00 \\
\hline 12. & EA & 60 & 80 & 60 & 66,67 \\
\hline 13. & ES & 60 & 60 & 60 & 60,00 \\
\hline 14. & FN & 40 & 80 & 0 & 40,00 \\
\hline 15. & $\mathrm{JM}$ & 60 & 80 & 40 & 60,00 \\
\hline 16. & LS & 20 & 60 & 60 & 46,67 \\
\hline 17. & MS1 & 60 & 80 & 20 & 53,33 \\
\hline 18. & $\mathrm{MM}$ & 60 & 80 & 60 & 66,67 \\
\hline 19. & MS2 & 60 & 80 & 60 & 66,67 \\
\hline 20. & NS & 20 & 60 & 20 & 33,33 \\
\hline 21. & OK & 80 & 80 & 60 & 73,33 \\
\hline 22. & OS1 & 60 & 60 & 60 & 60,00 \\
\hline 23. & OS2 & 60 & 80 & 60 & 66,67 \\
\hline 24. & PM & 60 & 80 & 60 & 66,67 \\
\hline 25. & RN & 60 & 60 & 60 & 60,00 \\
\hline 26. & $\mathrm{RS}$ & 60 & 80 & 60 & 66,67 \\
\hline 27. & SS1 & 40 & 80 & 0 & 40,00 \\
\hline 28. & SS2 & 60 & 40 & 60 & 53,33 \\
\hline 29. & SS3 & 60 & 60 & 60 & 60,00 \\
\hline 30. & SS4 & 60 & 60 & 40 & 53,33 \\
\hline 31. & TM & 60 & 60 & 60 & 60,00 \\
\hline 32. & TS & 40 & 60 & 20 & 40,00 \\
\hline 33. & $\mathrm{VN}$ & 40 & 80 & 60 & 60,00 \\
\hline 34. & WS1 & 60 & 80 & 60 & 66,67 \\
\hline 35. & WS2 & 60 & 60 & 80 & 66,67 \\
\hline 36. & YS & 40 & 60 & 20 & 40,00 \\
\hline \multicolumn{2}{|c|}{ Nilai rata-rata } & 55,00 & 69,44 & 47,78 & 57,41 \\
\hline
\end{tabular}

Tabel 2. Perbandingan Nilai Ulangan pre test dan post test I, II, dan III sebelum dibelajarkan dengan menggunakan model dengan setelah dibelajarkan dengan model pembelajaran CLIS, dan minat siswa .

\begin{tabular}{|l|l|l|l|}
\hline No. & \multicolumn{1}{|c|}{$\begin{array}{c}\text { Kelas VIIIB Belum } \\
\text { Dibelajarkan } \\
\text { Menggunakan Model } \\
\text { Pembelajaran CLIS }\end{array}$} & $\begin{array}{c}\text { Kelas VIII B Setelah } \\
\text { Dibelajarkan } \\
\text { Menggunakan Model } \\
\text { Pembelajaran CLIS }\end{array}$ & Keterangan \\
\hline 1. & $\begin{array}{l}\text { Rata-rata nilai } \\
\text { Hasil Ulangan } \\
\text { Pre test I }=55,00\end{array}$ & $\begin{array}{l}\text { Rata-rata nilai } \\
\text { Hasil Ulangan } \\
\text { Post test I }=91,11\end{array}$ & $\begin{array}{l}\text { Hasil belajar siswa yang } \\
\text { dibelajarkan dengan model } \\
\text { pembelajaran CLIS lebih tinggi }\end{array}$ \\
\hline
\end{tabular}




\begin{tabular}{|c|c|c|c|}
\hline 2. & $\begin{array}{l}\text { Rata- rata nilai } \\
\text { Hasil Ulangan } \\
\text { Pre tsst II }=69,44\end{array}$ & $\begin{array}{l}\text { Rata- rata nilai } \\
\text { Hasil Ulangan } \\
\text { Post test II }=97,78\end{array}$ & $\begin{array}{l}\text { Hasil belajar siswa yang } \\
\text { dibelajarkan dengan model } \\
\text { pembelajaran CLIS lebih tinggi }\end{array}$ \\
\hline 3. & $\begin{array}{l}\text { Rata- rata nilai } \\
\text { Hasil Ulangan } \\
\text { Pre test III }=47,78\end{array}$ & $\begin{array}{l}\text { Rata rata nilai } \\
\text { Hasil Ulangan } \\
\text { Post test III = 98,33 }\end{array}$ & $\begin{array}{l}\text { Hasil belajar siswa yang } \\
\text { dibelajarkan dengan model } \\
\text { pembelajaran CLIS lebih tinggi }\end{array}$ \\
\hline 4. & $\begin{array}{l}\text { Rata-rata Nilai } \\
\text { Hasil Ulangan pre } \\
\text { I, II, III sebelum } \\
\text { dibelajarkan dengan } \\
\text { model CLIS }=57,41\end{array}$ & $\begin{array}{l}\text { Rata rata Nilai } \\
\text { Hasil Ulangan Post test } \\
\text { I, II, III setelah } \\
\text { dibelajarkan dengan } \\
\text { model CLIS }=95,74\end{array}$ & $\begin{array}{l}\text { Hasil belajar siswa yang } \\
\text { dibelajarkan dengan model } \\
\text { pembelajaran CLIS jauh lebih } \\
\text { tinggi }\end{array}$ \\
\hline 5. & $\begin{array}{l}\text { Minat siswa terhadap } \\
\text { pelajaran IPA } \\
\text { tanpa menggunakan } \\
\text { model pembelajaran CLIS } \\
\text { setelah mengisi angket } \\
\text { hanya } 70 \% \text { yang senang. }\end{array}$ & $\begin{array}{l}\text { Minat siswa terhadap } \\
\text { Pelajaran IPA } \\
\text { dengan menggunakan } \\
\text { model pembelajaran } \\
\text { CLIS setelah } \\
\text { mengisi angket = } 100 \% \\
\text { sangat senang. }\end{array}$ & $\begin{array}{l}\text { Minat belajar siswa } \\
\text { yang menggunakan model } \\
\text { pembelajaran CLIS jauh lebih } \\
\text { tinggi dari pada minat belajar } \\
\text { siswa yang dibelajarakan } \\
\text { tanpa model pembelajaran CLIS }\end{array}$ \\
\hline
\end{tabular}

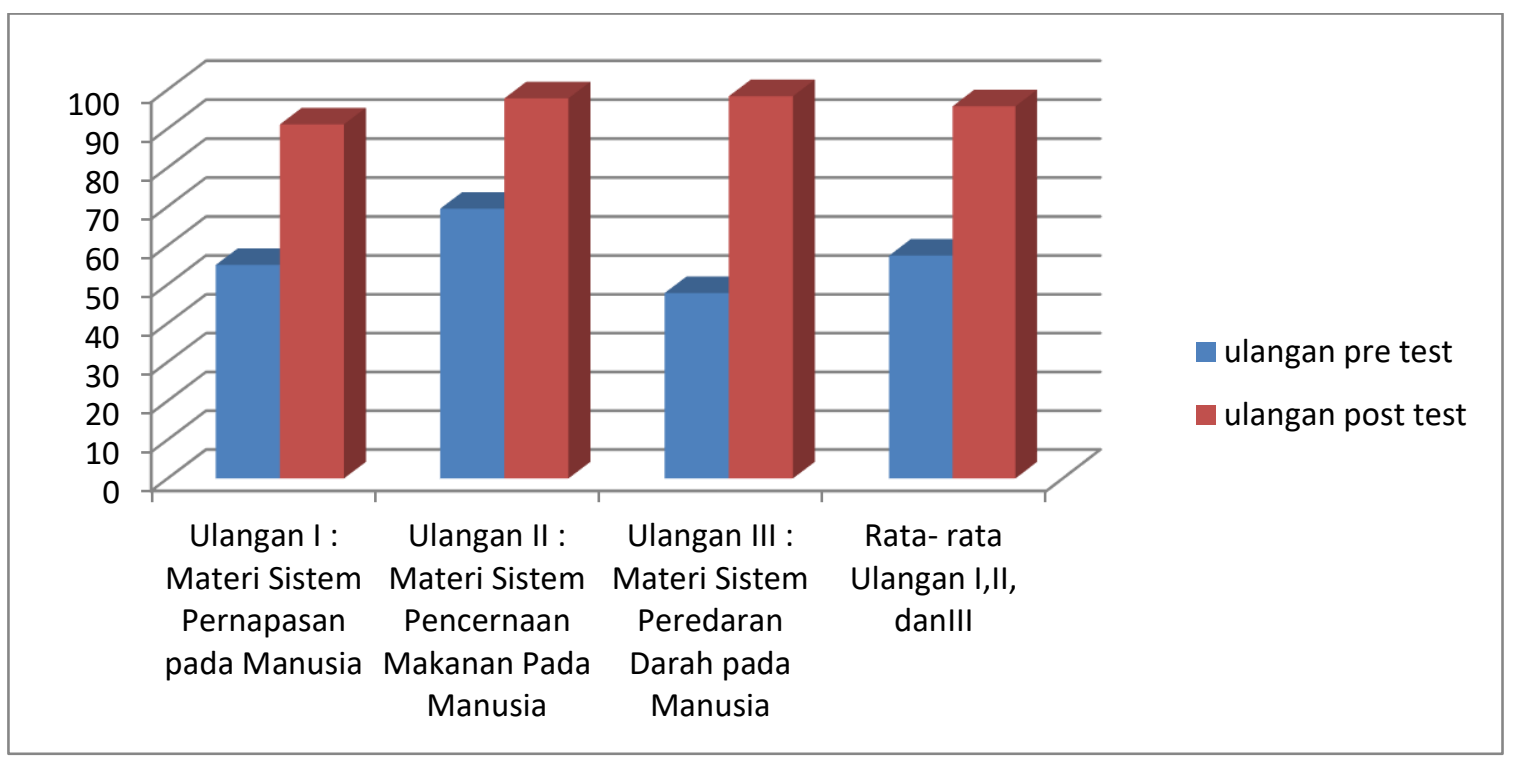

Gambar 1. Diagram batang Nilai Hasil Perolehan Siswa selama PBM pada siklus I, II dan ke III serta rata-rata nya dibandingkan sebelum dan sesudah dibelajarkan dengan model CLIS.

Untuk mendukung dan membuktikan terlaksananya penelitian ini, penulis membuat video pembelajaran lalu Kepala sekolah mengamati guru dalam pengajaran model CLIS dengan tabel berikut :

Tabel 3. Hasil Pengamatan guru dalam pengajaran model CLIS

\begin{tabular}{|c|c|c|c|c|c|}
\hline \multirow{2}{*}{ No } & Aspek kinerja guru yang dinilai & \multicolumn{3}{|c|}{ Siklus dalm (\%) } & \\
\cline { 4 - 6 } & \multicolumn{1}{|c|}{1} & 2 & 3 & Rata2 \\
\hline \multicolumn{2}{|c|}{ Orientasi } & & & & 83.33 \\
\hline $\mathbf{1}$ & $\begin{array}{l}\text { Menampilkan suatu fenomena yang sering terjadi dalam } \\
\text { kehidupan sehari-hari, yang berkaitan dengan topik yang } \\
\text { dipelajarai }\end{array}$ & 75 & 85 & 90 & 8 \\
\hline
\end{tabular}




\begin{tabular}{|c|c|c|c|c|c|}
\hline 2 & $\begin{array}{l}\text { Mengaitkan topik yang akan dipelajari dengan fenomena } \\
\text { lingkungan }\end{array}$ & 75 & 80 & 90 & 81.67 \\
\hline \multicolumn{6}{|c|}{ Pemunculan gagasan } \\
\hline 3 & $\begin{array}{l}\text { Memunculkan dan mengeksplorasi gagasan untuk } \\
\text { memunculkan konsepsi awal siswa }\end{array}$ & 75 & 85 & 90 & 83.33 \\
\hline 4 & $\begin{array}{l}\text { Mengajak siswa menuliskan atau menjawab apa saja yang } \\
\text { telah diketahui tentang topik pembicaraan }\end{array}$ & 70 & 80 & 85 & 78.33 \\
\hline \multicolumn{6}{|c|}{ Penyusunan ulang gagasan } \\
\hline 5 & $\begin{array}{l}\text { Memperjelas atau mengungkapkan gagasan awal siswa } \\
\text { tentang suatu topik secara umum dan mendiskusikan } \\
\text { jawaban siswa dalam kelompok kecil }\end{array}$ & 75 & 85 & 95 & 85.00 \\
\hline 6 & $\begin{array}{l}\text { Memberi kesempatan kepada siswa untuk mencari konsep } \\
\text { ilmiah yang sedang dipelajari }\end{array}$ & 80 & 85 & 90 & 85.00 \\
\hline 7 & $\begin{array}{l}\text { Membimbing siswa dalam mencari beberapa perbedaan } \\
\text { antara konsepsi awal dengan konsep ilmiah atau hasil } \\
\text { pengamatan }\end{array}$ & 80 & 85 & 90 & 85.00 \\
\hline 8 & $\begin{array}{l}\text { Memberi kesempatan kepada siswa untuk melaporkan hasil } \\
\text { diskusi }\end{array}$ & 70 & 75 & 85 & 76.67 \\
\hline \multicolumn{6}{|c|}{ Penerapan gagasan } \\
\hline 9 & $\begin{array}{l}\text { Mengarahkan siswa untuk menjawab pertanyaan yang } \\
\text { disusun untuk menerapkan konsep ilmiah yang telah } \\
\text { dikembangkan siswa ke dalam situasi baru }\end{array}$ & 75 & 80 & 85 & 80.00 \\
\hline 10 & $\begin{array}{l}\text { Menganalisis isu-isu dan memecahkan masalah yang ada } \\
\text { dilingkungan }\end{array}$ & 75 & 85 & 90 & 83.33 \\
\hline \multicolumn{6}{|c|}{ Pemantapan gagasan } \\
\hline 11 & $\begin{array}{l}\text { Memberi umpan balik untuk memperkuat konsep ilmiah } \\
\text { yang telah diperoleh siswa }\end{array}$ & 70 & 80 & 90 & 80.00 \\
\hline \multirow[t]{3}{*}{12} & $\begin{array}{l}\text { Memberi kesempatan kepada siswa untuk membandingkan } \\
\text { konsep ilmiah yang sudah disusun dengan konsep awal }\end{array}$ & 70 & 85 & 90 & 81.67 \\
\hline & Persentase kinerja guru & \multicolumn{4}{|c|}{$81,94 \%$} \\
\hline & Kategori kinerja guru & \multicolumn{4}{|c|}{ baik } \\
\hline
\end{tabular}

Keterangan: (1) tidak baik, (2) kurang baik, (3) baik, (4) sangat baik

Dari hasil pengamatan Kepala sekolah, ternyata Guru memiliki nilai kinerja Amat baik.

\section{PEMBAHASAN \\ Siklus Pertama}

Proses pembelajaran tentang Sistem Pernapasan pada Manusia, lokasi waktu 2 x 40 menit, pelaksanaan 5 Maret 2015, Dibelajarkan dengan model CLIS. Seluruh kegiatan pembelajaran berjalan dengan baik dan materi yang disampaikan sesuai dengan RPP. Pembelajaran diikuti oleh seluruh siswa. Penyajian materi pembelajaran dapat dilakukan dengan lebih mudah, lebih rinci dan lebih nyata karena menggunakan model pembelajaran CLIS guru sudah merakit pembelajaran sesuai dengan kehidupan nyata, guru memberikan kesempatan dan memotivasi siswa untuk meminta gagasangagasan dari siswa tentang pelajaran yang berlangsung. Pembelajaran dengan model CLIS ini dibantu dengan menggunakan media Lap Top berisi video pembelajaran, $\mathrm{CD}$ interaktif, gambar-gambar menarik dan berbagai animasi menarik yang disajikan dalam bentuk power point terutama memberikan kesempatan untuk membuktikan gagasan-gagasan itu melalui praktek /percobaan secara berkelompok dan berdiskusi, sangat membantu para siswa untuk memahami Mata Pelajaran IPA Sub topik Sistem Pernapasan pada manusia yang diajarkan.

Dalam proses pembelajaran, penulis mengamati bahwa: Minat belajar, keaktifan, dan semangat belajar para siswa yang proses pembelajarannya menggunakan model pembelajaran CLIS sangat tinggi, karena dengan menggunakan model pembelajaran CLIS, guru memberikan kesempatan dan memotivasi siswa untuk meminta gagasan-gagasan dari siswa tentang pelajaran yang berlangsung. Pembelajaran dengan model CLIS ini dibantu dengan menggunakan media Lap Top berisi video pembelajaran, cd interaktif, gambargambar menarik dan berbagai animasi menarik yang disajikan dalam bentuk power point terutama memberikan kesempatan untuk 
membuktikan gagasan-gagasan itu melalui praktek /percobaan secara berkelompok dan berdiskusi. Nilai hasil ulangan siswa setelah dibelajarkan dengan model pembelajaran CLIS lebih tinggi daripada nilai hasil ulangan siswa sebelum dibelajarkan dengan model pembelajaran CLIS.

\section{Siklus kedua}

Proses pembelajaran tentang Sistem Pencernaan makanan pada Manusia, lokasi waktu 2 x 40 menit, pelaksanaan 12 Maret 2015, Dibelajarkan dengan model CLIS. Seluruh kegiatan pembelajaran berjalan dengan baik dan materi yang disampaikan sesuai dengan RPP. Pembelajaran diikuti oleh seluruh. Penyajian materi pembelajaran dapat dilakukan dengan lebih mudah, lebih rinci dan lebih nyata karena menggunakan model pembelajaran CLIS guru sudah merakit pembelajaran sesuai dengan kehidupan nyata, guru memberikan kesempatan dan memotivasi siswa untuk meminta gagasangagasan dari siswa tentang pelajaran yang berlangsung. Pembelajaran dengan model CLIS ini dibantu dengan menggunakan media Lap Top berisi video pembelajaran, cd interaktif, gambargambar menarik dan berbagai animasi menarik yang disajikan dalam bentuk power point terutama memberikan kesempatan untuk membuktikan gagasan-gagasan itu melalui praktek /percobaan secara berkelompok dan berdiskusi, sangat membantu para siswa untuk memahami Mata Pelajaran IPA Sub topik Sistem pencernaan makanan pada manusia yang diajarkan.

Dalam proses pembelajaran, penulis mengamati bahwa: Minat belajar, keaktifan, dan semangat belajar para siswa yang proses pembelajarannya menggunakan model pembelajaran CLIS sangat tinggi, karena dengan menggunakan model pembelajaran CLIS, guru memberikan kesempatan dan memotivasi siswa untuk meminta gagasan-gagasan dari siswa tentang pelajaran yang berlangsung. Pembelajaran dengan model CLIS ini dibantu dengan menggunakan media Lap Top berisi video pembelajaran, cd interaktif, gambargambar menarik dan berbagai animasi menarik yang disajikan dalam bentuk power point terutama memberikan kesempatan untuk membuktikan gagasan-gagasan itu melalui praktek/percobaan secara berkelompok dan berdiskusi. Nilai hasil ulangan siswa setelah dibelajarkan dengan model pembelajaran CLIS lebih tinggi daripada nilai hasil ulangan siswa sebelum dibelajarkan dengan model pembelajaran CLIS.

\section{Siklus ketiga}

Proses pembelajaran tentang Sistem Peredaran darah manusia, lokasi waktu 2 x 40 menit, pelaksanaan 19 Maret 2015, Dibelajarkan dengan model CLIS. Seluruh kegiatan pembelajaran berjalan dengan baik dan materi yang disampaikan sesuai dengan RPP. Pembelajaran diikuti oleh seluruh. Penyajian materi pembelajaran dapat dilakukan dengan lebih mudah, lebih rinci dan lebih nyata karena menggunakan model pembelajaran CLIS guru sudah merakit pembelajaran sesuai dengan kehidupan nyata, guru memberikan kesempatan dan memotivasi siswa untuk meminta gagasangagasan dari siswa tentang pelajaran yang berlangsung. Pembelajaran dengan model CLIS ini dibantu dengan menggunakan media Lap Top berisi video pembelajaran, cd interaktif, gambargambar menarik dan berbagai animasi menarik yang disajikan dalam bentuk power point terutama memberikan kesempatan untuk membuktikan gagasan-gagasan itu melalui praktek /percobaan secara berkelompok dan berdiskusi, sangat membantu para siswa untuk memahami Mata Pelajaran IPA Sub topik Sistem peredaran darah pada manusia yang diajarkan.

Dalam proses pembelajaran, penulis mengamati bahwa: Minat belajar, keaktifan, dan semangat belajar yang proses pembelajarannya menggunakan model pembelajaran CLIS sangat tinggi, karena dengan menggunakan model pembelajaran CLIS, guru memberikan kesempatan dan memotivasi siswa untuk meminta gagasan-gagasan dari siswa tentang pelajaran yang berlangsung. Pembelajaran dengan model CLIS ini dibantu dengan menggunakan media Lap Top berisi video pembelajaran, cd interaktif, gambar-gambar menarik dan berbagai animasi menarik yang disajikan dalam bentuk power point terutama memberikan kesempatan untuk membuktikan gagasan-gagasan itu melalui praktek /percobaan secara berkelompok dan berdiskusi. Nilai hasil ulangan siswa Kelas VIIIB setelah dibelajarkan dengan model pembelajaran CLIS lebih tinggi daripada nilai hasil ulangan siswa sebelum dibelajarkan dengan model pembelajaran CLIS.

\section{PENUTUP \\ Simpulan}

Berdasarkan hasil penelitian yang telah dilakukan dapat ditarik kesimpulan sebagai berikut: 
1. Model pembelajaran meningkatkan prestasi belajar siswa khususnya pada mata pelajaran IPA di SMP Negeri 1 Pangururan Kelas VIIIB, dibuktikan dengan peningkatan hasil penelitian dari Rata-rata nilai ulangan pre test I, II, III = 57,41 sedangkan Rata-rata nilai ulangan post test I, II, III = 95,74 dan semua siswa setelah dibelajarkan dengan model CLIS tidak ada yang dibawah KKM (70) .

2. Dengan meningkatnya hasil belajar dan minat belajar siswa maka prestasi belajar siswa ikut meningkat, dengan demikian guru sebagai pendidik ikut membumi landaskan Revolusi Mental bagi peserta didik dalam Menyiapkan Generasi Emas 2045.

\section{Saran}

Berdasarkan penemuan penulis dalam penelitian tindakan kelas ini, maka penulis menyarankan beberapa hal sebagai berikut :

a. Kementerian Pendidikan Nasional maupun Dinas Pendidikan Daerah hendaknya semakin menggalakkan program pelatihanpelatihan kepada para guru untuk meningkatkan kualitasnya di bidang pendidikan terutama dalam mengembangkan model-model pembelajaran, dan mewajibkan setiap guru ikut lomba uji kompetensi guru setiap tahunnya, sehingga setiap guru akan berusaha untuk membuat yang terbaik dalam pembelajarannya yang nantinya akan berdampak positif bagi peningkatan mutu pendidikan.

b. Para guru, khususnya guru mata pelajaran IPA agar dapat menerapkan berbagai model pembelajaran yang sesuai dengan topik pembelajarannya, seperti model pembelajaran CLIS sangat cocok untuk mata pelajaran IPA, mengingat materi IPA banyak membahas topik yang dapat dilihat secara nyata oleh para siswa sehingga hasil belajar siswa dapat lebih baik lagi pada masa-masa mendatang.

\section{DAFTAR PUSTAKA}

Djamarah, syaiful Bahri.Prestasi Belajar dan Kompetensi Guru (Surabaya : Usaha Nasional, 1994) hal 23

http.www.mbahbreta - edu blogspot.com diakses tgl 29 Maret 2015

https : // azharmzk. Wordpress.com/2012/05/09/ defenisi-pengertian-dan-faktor-faktor yang mempengaruhi - prestasi - belajar

Indrianto, Bambang. 2008. Peraturan Menteri Pedidikan Nasional. Jakarta Pusat: Departemen Pendidikan Nasional.

Materi Pelatihan Kurikulum Tingkat Satuan Pendidikan (KTSP). 2008. Jakarta: Depdiknas.

Penulisan Karya Ilmiah. 2008. Jakarta: Direktorat Tenaga Kependidikan Direktorat Jenderal Peningkatan Mutu Pendidik Dan Tenaga Kependidikan Departemen Pendidikan Nasional.

Subratha, 2007 : 135-136. Pembelajaran IPA dimaksudkan untuk membentuk sikap yang positif

Sudibyo, Bambang. 2008. Materi Pelatihan Kurikulum Tingkat Satuan pendidikan (KTSP). Jakarta Pusat: Departemen Pendidikan Nasional.

Surianta, Eddi. 2007. Penyusunan Karya Tulis Ilmiah. Medan: LPMP Propinsi Sumatera Utara.

Tim Prima Pena. 2007. Kamus Besar Bahasa Indonesia. Jakarta: Gita Media Press.

Undang-Undang Nomor 20 Tahun 2003 Undang-undang tentang Sistem Pendidikan Nasional.

Kumpulan Peraturan Menteri Pendidikan Nasional. 2008. Jakarta: Direktur Jenderal Manajemen Pendidikan Dasar dan Menengah.

Sriyono, aktivitas belajar (http://www.scribd.com/doc/9037208/BA B-II-edit), 1992,hal. 7.

www. Matrapendidikan. com/2013/09/tips ampuh - menjadi - siswa berprestasi -26 html

www.bbc. Com /Indonesia /majalah / 2015 / 05/ 150513- majalah - asia - sekolah terbaik. 